\title{
KESULITAN SISWA DALAM MEMAHAMI KONSEP TRIGONOMETRI DI LIHAT DARI LEARNING OBSTACLES
}

\author{
Mohamad Gilar Jatisunda ${ }^{1}$, Dede Salim Nahdi ${ }^{2}$ \\ ${ }^{1}$ Pendidikan Matematika, Universitas Majalengka \\ ${ }^{2}$ Pendidikan Guru Sekolah Dasar, Universitas Majalengka \\ g.jatisunda@unma.ac.id
}

\begin{abstract}
Abstrak-Studi ini mengungkapkan bagaimana pemahaman konseptual siswa tentang konsep triginometri. Meskipun guru telah menjelaskan prosedur operasi dalam konsep trigonometri, tetapi siswa masih mengalami kesulitan dalam memahami konsep trigonometri, sehingga prosedur yang ditempuh selanjutnya menjadi terhambat. Kemudian mengembangkan desain didaktis berdasarkan kesulitan siswa. Penelitian ini merupakan penelitian desain menggunakan kerangka didactical design research dengan menggunakan pendekatan kualitatif. Data dikumpulkan melalui uji kemampuan siswa melalui tes tertulis, wawancara dan observasi. Hasil penelitian menunjukkan bahwa siswa mengalami kesulitan disebabkan karena hambatan belajar konsep trigonometri, Hasil implementasi dari desain didaktis awal ini secara umum sesuai dengan prediksi respon siswa yang telah dibuat sebelumnya. Selama proses pengimplementasian ada beberapa respon siswa yang tidak sesuai dengan prediksi sebelumnya, namun hal ini dapat diatasi dengan baik.
\end{abstract}

Kata kunci: Kesulitan Siswa, Tigonometri, Didactical Design Research 


\section{PENDAHULUAN}

Pemahaman bukan hanya mengetahui suatu informasi, melainkan lebih dari itu siswa dapat memaknai dan mentransformasi suatu informasi tersebut kedalam wujud lain yang lebih berarti, sehingga dapat membantu siswa dalam pemecahan masalah matematika yang lebih sulit. Akibatnya kemampuan pemahaman matematis sangat penting dalam pembelajaran matematika. Hiebert and Carpenter (1992) dalam Juan D. Godino “one of the most widely accepted ideas in mathematics education is that students should understand mathematics". Begitu juga menurut Hung-Hsi Wu (1999: 1) The truth is that in mathematics, skills and understanding are completely intertwined. In most cases, the precision and fluency in the execution of the skills are the requisite vehicles to convey the conceptual understanding. Kemampuan pemahaman konseptual merupakan salah satu kemampuan matematika yang penting di kuasai oleh siswa dalam pembelajaran, memberi pengertian hal yang perlu dilihat secara seksama dalam pembelajaran. Akibat dari itu proses pembelajaran harus memperhatikan keadaan terutama kemampuan siswa. Menurut Baljit Kaur (2012: 11) Learning is not just about acquisition; it is meant to be about participation. And there is an increasing emphasis on catering effectively to students from diverse backgrounds and different abilities within the classroom without "othering" them.

Fakta di lapangan menunjukkan bahwa proses pembelajaran di kelas masih cenderung menekankan pengetahuan konsep yang dipelajari, sedangkan kemampuan siswa memahami secara konseptual hanya diberikan kesempatan dalam waktu yang sangat singkat sehingga siswa sering membuat kesalahan dalam memecahkan masalah yang diberikan.
Salah satu contohnya dalam pembelajaran Trigonometri. Yulandari(2012) dalam Siti Sofiyah (2018: 23) Trigonometry is a material that is considered difficult by most students in mathematics subjects so that students experience confusion in its application. Hülya Gür (2009: 68) Trigonometry is an area of mathematics that students believe to be particularly difficult and abstract compared with the other subjects of mathematics. Blackett \& Tall, 1991 dalam Keith Weber (2005: 91) Unfortunately, the initial stages of learning about trigonometric functions are fraught with difficulty.

Lebih spesifik penulis berdasarkan wawancara dengan beberapa siswa, pada pembelajaran materi trigonometri tahap awal siswa kesulitan mempelajari ide-ide tentang trigonometri, teurtama konsep segitiga siku-siku sebagai awal konsep trigonometri. Blackett and Tall (1991) dalam Melike Özüdoğru (2017: 754) It requires the learner to relate shapes of triangles to numerical relationships to cope with ratios such as $\sin A=$ opposite/hypotenuse and to manipulate the symbols involved in such relationships. Hal tersebut di perkuat dengan teori piaget tentang operasi formal pada siswa di mana menurut Hülya Gür (2018; 13) Many misconceptions are related to a concept that produces a mathematical object and symbol. For example: sine is a concept and symbol of trigonometric functions.

Mata pelajaran Matematika, khususnya trigonometri adalah salah satu mata pelajaran sekolah yang sangat sedikit disukai dan hanya sebagian siswa yang berhasil dalam belajar trigonometri, hanya siswa yang mempunyai keyakinan yang baik terhadap trigonometri yang berhasil. Sukmadewi (2014: 130) Productive disposition refers to the tendency to see sense in mathematics, to perceive it as both useful and worthwhile, to believe that 
steady effort in learning mathematics pays off, and to see oneself as an effective learner and doer of mathematics. Sehingga peran siswa sangat menentukan sekali terhadap keberhasilan mereka dalam proses tercapainya tujuan pembelajaran. Pandangan siswa terhadap matematika bahwa matematika itu berguna dan bermanfaat. Tanpa mempunyai pandangan terhadap matematika seperti itu menyebabkan sebagian besar siswa memiliki kemampuan konseptualisasi yang terbatas karena mereka belajar dalam struktur dan pengarahan yang kaku. Efraim Fischbein (1989: 12) A fundamental characteristic of a mental model is that it is a structural entity. A model, like a theory, is not a simple isolated rule but, rather, a global, unitary, meaningful interpretationof a phenomenon or a concept. Hal tersebut mengakibatkan ketika dihadapkan pada permasalahan yang baru, siswa mengalami kesulitan untuk menyelesaikannya karena konsepkonsep yang tidak mereka pahami secara menyeluruh. Pemahaman terhadap konsep yang tidak utuh inilah yang nantinya menimbulkan hambatan belajar (learning obstacle)

Pada studi pendahuluan yang dilakukan peneliti mengenai perbandingan trigonometri kepada beberapa orang responden mahasiswa Jurusan Pendidikan Matematika, diperoleh empat macam learning obstacle yang dialami responden khususnya ketika mengerjakan soal mengenai perbandingan trigonometri. Ditinjau dari learning obstacle yang diperoleh dari penelitian pendahuluan, salah satu penyebab timbulnya kesulitan mahasiswa dalam memahami konsep perbandingan trigonometri adalah karena terbiasanya menghafal rumus tanpa mengetahui dari mana rumus tersebut berasal. Oleh karena itulah untuk mengurangi munculnya hambatan belajar (learning obstacle) ini maka perlu membuat suatu rancangan bahan ajar (desain didaktis), dimana desain ini dikembangkan berdasarkan sifat konsep yang akan disajikan dengan memperhatikan learning obstacle yang telah di identifikasi.

Berdasarkan pandangan tersebut di atas, penelitian ini dimaksudkan untuk mengetahui pemahaman konseptual siswa tentang materi trigonometri. Dengan studi yang lebih khusus terkait dengan kesulitan siswa dalam memahami konsep-konsep trigonometri.

\section{METODE PENELITIAN}

Desain yang digunakan dalam penelitian ini adalah desain penelitian kualitatif. Penelitian ini menggunakan kerangka metodologis Didactical Design Research (DDR) yang dikembangkan oleh Suryadi (2010). Menurut Suryadi (2018) DDR atau penelitian desain didaktis yang dikembangkannya menggunakan landasan filosofis hermeneutika, fenomenologi dan ethnomethodology.

\section{HASIL DAN PEMBAHASAN \\ a. Pengembangan Desain Didaktis Berdasarkan Learning Obstacle}

Penelitian ini merupakan penelitian lanjutan dari penelitian awal yang telah dilakukan sebelumnya. Pada penelitian awal, diadakan uji learning obstacle terkait materi perbandingan trigonometri. Berdasarkan pengujian awal tersebut, maka diperoleh learning obstacle yang dialami oleh siswa dalam konsep perbandingan trigonometri yaitu sebagai berikut: (1) Siswa mengalami kesulitan terkait rumus nilai perbandingan trigonometri. Hal ini terlihat dari adanya beberapa siswa yang masih tertukar dalam menggunakan rumus-rumus dari nilai perbandingan trigonometri. Selain itu 
kebanyakan siswa tidak mengetahui bahwa rumus-rumus tersebut hanya bisa digunakan pada segitiga siku-siku saja. (2) Siswa mengalami kesulitan terkait nilai-nilai perbandingan trigonometri pada sudut istimewa. (3) Siswa mengalami kesulitan dalam menyelesaikan soal-soal yang membutuhkan pengkonstruksian. Siswa mengalami kesulitan terkait variasi informasi yang diberikan. Untuk mengatasi kesulitan-kesulitan tersebut, maka ada langkah-langkah yang perlu dilakukan oleh guru sehingga diharapkan learning obstacle tersebut tidak muncul lagi atau minimal dapat dikurangi. Langkahlangkah pembelajaran tersebut selanjutnya kita sebut dengan pengembangan desain didaktis berdasarkan learning obstacle.

b. Desain Didaktis untuk Mengatasi

Kesulitan terkait Rumus Nilai Perbandingan Trigonometri

Pemberian materi perbandingan trigonometri ini diawali dengan apersepsi terhadap materi kesebangunan. Berikut sajian dari desain dalam apersepsi tentang materi kesebangunan untuk menemukan konsep sinus.

\section{Perhatikan segitiga siku-siku yang sebangun dib bawah ini}

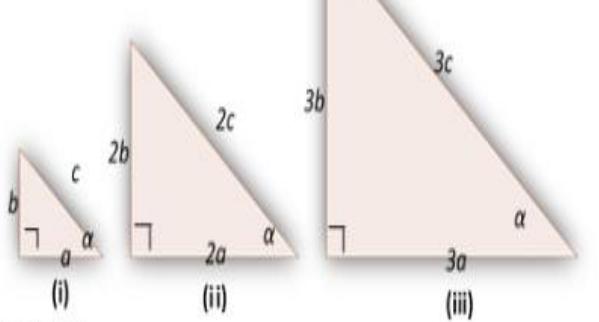

Kegiatan 1

Mengapa segitiga-segitiga di atas dikatakan sebaga segitiga-segitiga yang sebangun? Berikan alasanmu

Gambar 2. Desain Materi kesebangunan untuk menemukan konsep sinus.

Proses diatas dilakukan dengan tujuan untuk mengingatkan siswa kepada materi kesebangunan yang nantinya akan digunakan untuk menemukan konsep dari sinus. Hal ini sesuai dengan teori APOS yang diperkenalkan oleh Ed Dubinsky \& Michael A. McDonald "The theory we present begins with the hypothesis that mathematical knowledge consists in anindividual's tendency to deal with perceived mathematical problem situations by constructing mentalactions, processes, and objects and organizing them in schemas to make sense of the situations andsolve the problems". Adapun yang dimaksud dengan action disini adalah suatu transformasi obyek-obyek mental untuk memperoleh obyek mental lainnya. Hal tersebut dialami oleh seseorang pada saat menghadapi suatu permasalahan serta berusaha menghubungkannya dengan pengetahuan yang telah dimiliki sebelumnya.

\section{c. Efektivitas Desain Didaktis}

Untuk melihat sejauh mana efektifitas dari desain didaktis ini, maka setelah proses pengimpelementasian desain didaktis selesai, mahasiswa diberikan soal yang digunakan untuk identifikasi learning obstacle pada penelitian awal. Penghitungan efektifitas dari desain didaktis ini menggunakan rumus yang diadaptasi dari gain ternomalisasi Hake. Selain efektifitas dari desain didaktis, peningkatan kemampuan mahasiswa dalam memahami materi perbandingan trigonometri juga dapat dilihat melalui proses pengerjaan yang dilakukan mahasiswa pada uji soal dengan indikator kemampuan memahami bagian-bagian dari konsep tersebut. Berikut hasil analisis kemampuan mahasiswa tiap butir soal beserta proses pengerjaan yang dilakukan mahasiswa.

\section{Soal nomor 1}

Ghazia sedang berada di atas puncak Bintang dengan ketinggian 300m, karena akan bermain paralayang. Dia 
melihat Bukit Panten di sebelah utara dengan sudut depresi $30^{\circ}$ dan ketinggian $270 \mathrm{~m}$. Rencananya Bimo akan mendarat tepat di puncak Bukit Panten tersebut. Buatlah sketsa dari informasi di atas! Buatlah soal dan jawaban dari informasi diatas!

Salah satu contoh jawaban siswa :

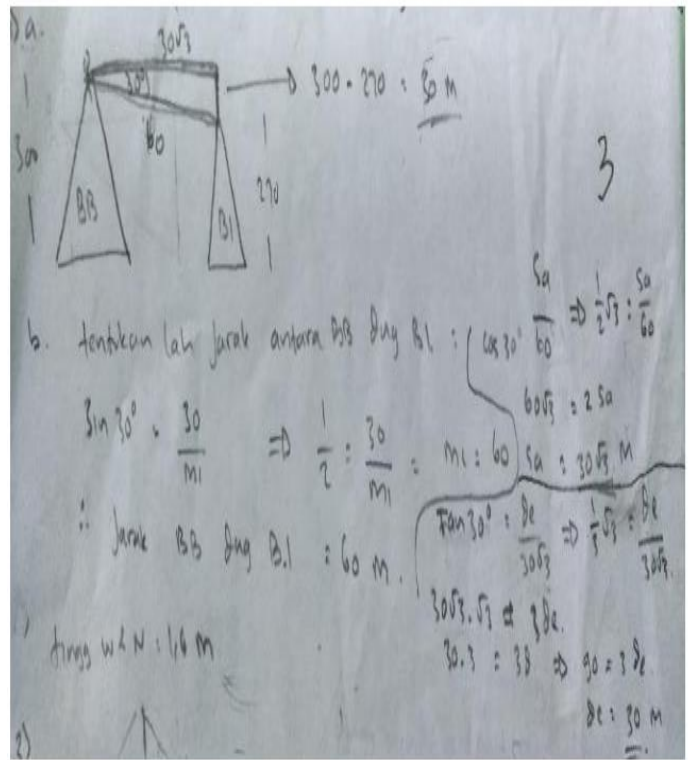

Gambar 4. Jawaban siswa yang menjawab benar

Berdasarakan jawaban siswa diata, siswa mampu memberikan satu cara secara fasih dan satu cara yang belum diselesaikan dengan penyelesaian yang baru atau tidak umum. Namun, terlihat kesalahan yang dilakukan adalah tidak menuliskan unsur-unsur yang diketahui, siswa hanya memberikan sketsa gambar yang lengkap, membuat satu masalah dan tidak menyelesaikan cara lain untuk mengecek jawabannya. Berdasarkan hasil wawancara siswa menyatakan bahwa dalam penyelesaian masalah, siswa mencoba lebih teliti dalam membuat sketsa gambar yang diminta pada soal, yaitu dalam membedakan sudut elevansi dan depresi, dan mencoba untuk mengembangkan cara penyelesaian yang pernah diberikan guru.

Tetapi ada juga siswa tidak bisa menjawab, dari hasil jawaban siswa terlihat siswa tersebut tidak memahami konteks soal yang diberikan, sehingga kesulitan mengintrepetasikan soal. Berdasarkan hasil wawancara pada siswa menyatakan bahwa tidak tahu bagaimana menganalisis soal cerita kepada gambar, lupa dengan istilah sudut depresi sehingga siswa tidak percaya diri dalam melanjutkan jawabnnya seperti yang terlihat pada Gambar di bawah ini.

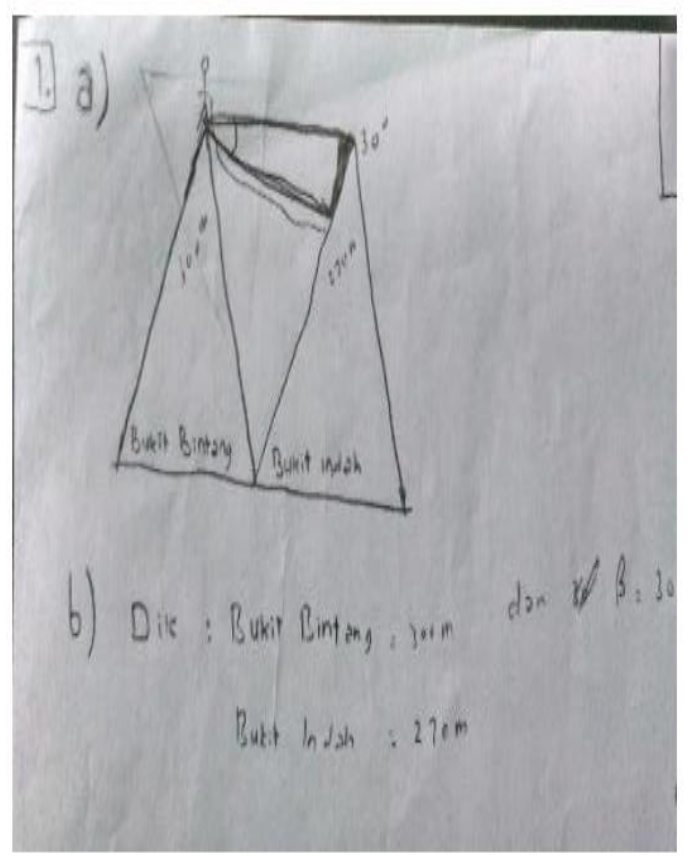

Gambar 5. Jawaban siswa yang salah Soal nomor 2

Rizmi memiliki tinggi badan yang sama dengan Ibad yaitu $160 \mathrm{~cm}$. Rizmi dan Ibad sedang mengamati sebuah menara. Rizmi berdiri tepat $15 \mathrm{~m}$ dari menara dan melihat puncak menara tersebut membentuk sudut elevansi $45^{\circ}$. Pada arah yang berlawanan Ibad melakukan hal yang sama dengan berdiri di atas loteng rumahnya dengan ketinggian $10 \mathrm{~m}$ dengan jarak menara dan rumahnya $5 \mathrm{~m}$. Dari data diatas, jelaskan dengan menggunakan aljabar, bagaimana cara untuk mencari tinggi menara dan sudut elevansi yang terbentuk saat Ibad melihat menara! Buatkan pula sketsanya!

Contoh jawaban siswa : 


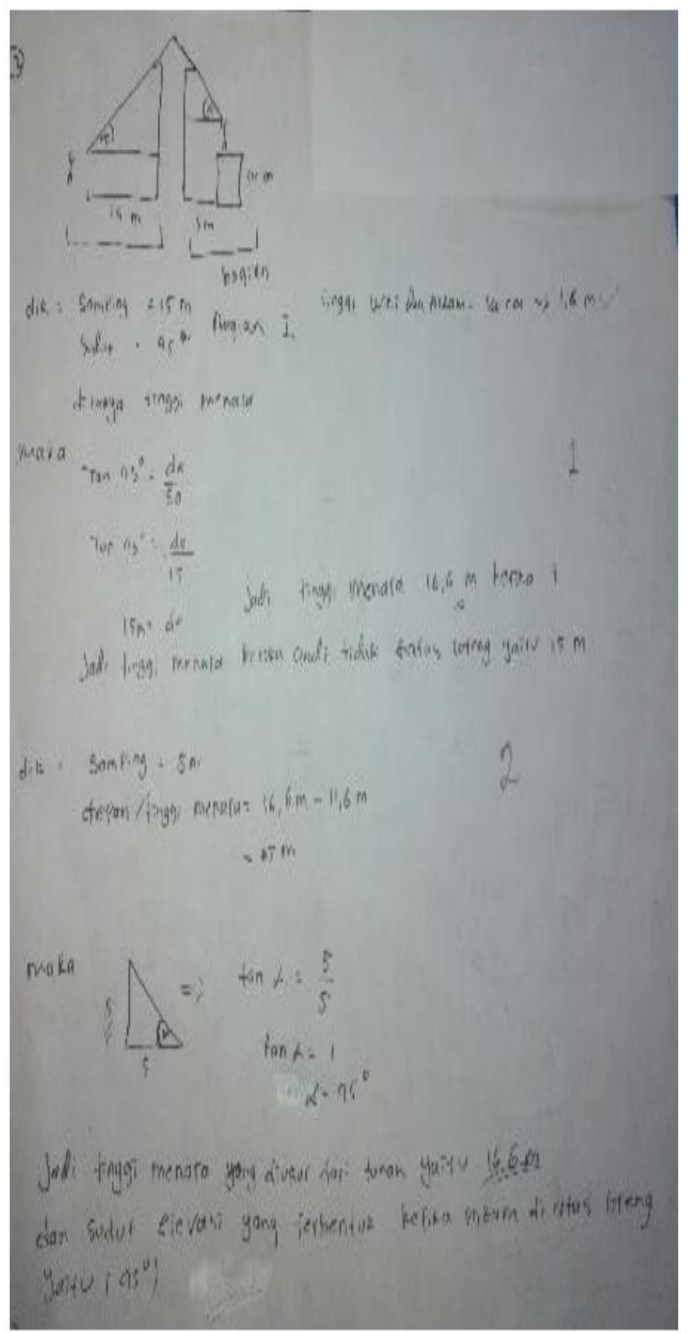

Gambar 6. Jawaban siswa yang benar

Siswa mampu memberikan satu cara secara fasih dengan sistematis. Terlihat yang dilakukan siswa adalah menuliskan unsur-unsur yang diketahui, kemudian menyelesaikan soal dengan menganalisis yang harus dikerjakan terlebih dahulu oleh siswa. Namun, siswa tersebut hanya membuat satu penyelesaian, sehingga hanya memberikan jawaban yang sederhana sesuai dengan permintaan soal. Berdasarkan hasil wawancara siswa menyatakan bahwa dalam penyelesaian masalah, siswa mencoba merinci langkah-langkah penyelesaian, yaitu dengan mencari tinggi menara tersebut dengan menggunakan konsep perbandingan segitiga siku-siku. Namun masih ada siswa yang tidak mampu memberikan alternatif penyelesaian masalah baik secara baru, berbeda dan beragam, berikut sempel hasil jawaban siswa:

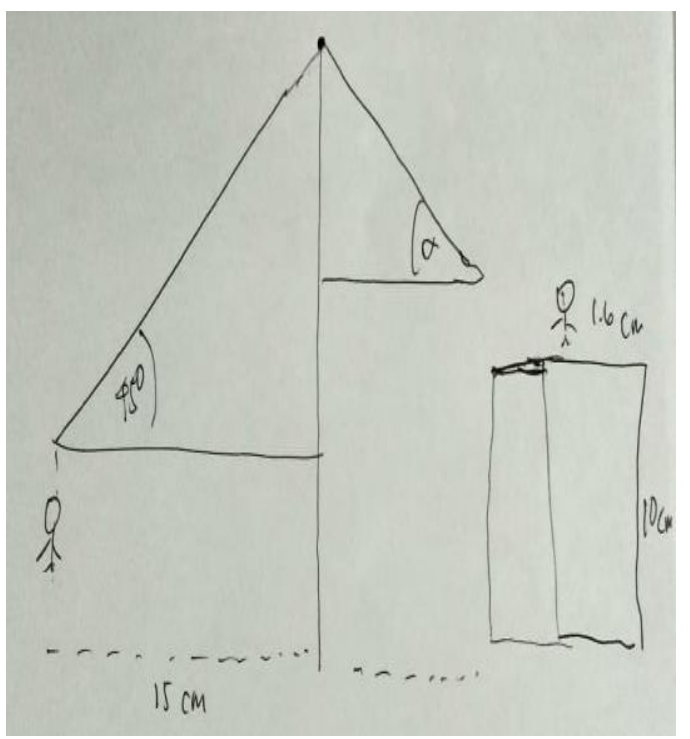

Gambar 7. Jawaban siswa yang salah Berdasarkan hasil wawancara pada siswa, menyatakan bahwa tidak tahu bagaimana mengerjakan soal tersebut, karena siswa beranggapan soal tersebut tidak bisa diselesaikan karena unsur yang diketahuinya tidak lengkap dan tidak tahu bagaimana mencari unsurunsur tersebut.

\section{KESIMPULAN}

Berdasarkan hasil penelitian dan pembahasan yang telah dipaparkan sebelumnya, maka dapat disimpulkan hal-hal sebagai berikut:

1. Pada penelitian awal atau penelitian pendahuluan peneliti memberikan soal mengenai perbandingan trigonometri kepada responden yang terdiri dari siswa. Yang telah menerima materi trigonometri. Berdasarkan penelitian tersebut diperoleh empat macam learning obstacle yang dialami oleh responden, yaitu:

a. Learning obstacle yang pertama terkait rumus nilai perbandingan trigonometri. 
Hal ini terlihat dari adanya beberapa siswa yang masih tertukar dalam penggunaan rumus-rumus perbandingan trigonometri.

b. Learning obstacle yang kedua terkait nilainilai perbandingan trigonometri pada sudut istimewa. Hal ini terlihat dari banyaknya siswa yang sering tertukar dalam menentukan nilai sinus, cosinus dan tangen dari sudut-sudut istimewa.

c. Learning obstacle yang ketiga terkait dengan informasi tersirat dalam soal yang diberikan sehingga mahasiswa harus mengkontruksi terlebih dahulu informasi tersebut.

d. Learning obstacle yang terakhir yaitu terkait variasi informasi yang diberikan. Ada dua macam variasi informasi yang membuat siswa mengalami kesulitan dalam mengerjakan soal, yaitu variasi informasi dengan menggunakan bentuk non rutin dan variasi informasi terkait konsep matematika yang lain.

2. Desain didaktis awal konsep perbandingan trigonometri disusun berdasarkan learning obstacle yang diperoleh pada penelitian tahap 1 dan diperkuat dengan teori-teori belajar yang relevan.Bentuk sajian desain didaktis yang telah disesuaikan dengan karakteristik ini disusun menjadi empat bagian, yaitu:

a. Desain didaktis untuk mengatasi kesulitan terkait rumus nilai perbandingan trigonometri disajikan dengan memberikan permasalahanpermasalahan yang menuntun siswa untuk menemukan sendiri rumus tersebut. b. Desain didaktis untuk mengatasi kesulitan terkait nilai-nilai perbandingan trigonometri pada sudut-sudut istimewa disajikan dengan memberikan permasalahan yang menuntun siswa untuk menemukan sendiri nilai perbandingan trigonometri pada sudut istimewa.

c. Desain didaktis untuk mengatasi kesulitan dalam menyelesaikan soal-soal yang membutuhkan

pengkonstruksian disajikan dengan memberikan soal-soal yang menuntut siswa untuk mengkonstruksi informasi yang diberikan sehingga mempermudah proses penyelesaian soal tersebut.

d. Desain didaktis untuk mengatasi kesulitan terkait variasi informasi yang diberikan disajikan dengan memberikan soal-soal yang memiliki informasi dalam bentuk non rutin atau informasi terkait konsep matematika yang lain, seperti konsep luas segitiga.

e. Hasil implementasi dari desain didaktis awal ini secara umum sesuai dengan prediksi respon siswa yang telah dibuat sebelumnya. Selama proses pengimplementasian ada beberapa respon siswa yang tidak sesuai dengan prediksi sebelumnya, namun hal ini dapat diatasi dengan baik.

\section{REFERENSI}

Fischbein, Efraim.(1989). Tacit Models and Mathematical Reasoning. or the Learningof Mathematics. FLM Publishing Association, Montreal, Quebec, Canada. 
Hülya, Gür. (2018). Trigonometry Learning. New Horizons in Education, Vol.57, No.1, May 2009.

Hülya, Gür. (2018). Trigonometry Learning. New Horizons in Education, Vol.57, No.1, May 2009.

Juan D. Godino. Mathematical Concepts, Their Meanings, And Understanding. In L. Puig y A. Gutierrez (Eds.), Proceedings of XX Conference of the International Group for the Psychology of Mathematics Education. (v.2, pp. 417-425). Universidad de Valencia.

Kaur, Baljit.(2012).Understanding Teaching and Learning Classroom Research Revisited. Published by: Sense Publishers, P.O. Box 21858, 3001 AW Rotterdam, The Netherlands.

http://www.sensepublishers.co $\mathrm{m} /$

Keith Weber (2005) Students' Understanding of Trigonometric Functions. Mathematics Education Research Journal 2005, Vol. 17, No. 3, 91-112

Özüdoğru, Melike. (2017). Mathematics Course Needs Assessment For Trigonometry Sub-Learning Area. Uluslararası Sosyal Araştırmalar Dergisi / The Journal of International Social Research Cilt: 10 Sayı: 54 Y1l: 2017 Volume: 10 Issue: $54 \quad$ Year: 2017 www.sosyalarastirmalar.com

Issn: 1307-9581 http://dx.doi.org/10.17719/jisr.2 0175434643

Sofiyah, Siti (2018: 23) International Journal of Management and Applied Science, ISSN: 2394-7926 Volume-4， Issue-5, May-2018 http://iraj.in Analysis of Students Error in Proving Trigonometric Identities
Sukmadewi, T., S.(2014: 130) Improving Students' Mathematical Thinking And Disposition Through Probing And Pushing Questions. Jurnal Matematika Integratif ISSN 1412-6184 Volume 10 No 2, Oktober 2014 , pp 127-137

Suryadi, D. (2008). Metapedadidaktik dalam Pembelajaran Matematika: Suatu

Strategi Pengembangan Diri Menuju Guru Profesional. Pidato Pengukuhan

Guru Besar.

Suryadi, D. (2010). Didactical design research (DDR) dalam pengembangan

pembelajaran matematika. In Bandung: Seminar Nasional Pembelajaran MIPA di UM Malang (Vol. 13).

Suryadi, D. (2018). Landasan Filosofis Penelitian Desain Didaktis (DDR). Tidak dipublikasikan

Wu, Hung-Hsi. (1999). Basic Skills Versus Conceptual Understanding. American Educator/American Federation Of Teachers 